\title{
Analisis Event Terhadap Peningkatan Occupancy Pada Hotel Bintang 3 (***) Di Kota Pekanbaru: Study Kasus Pada Hotel Swiss-Belinn Pekanbaru
}

\author{
SEFRONA SYAIFUL \\ Sekolah Tinggi Pariwisata Riau \\ J1. Pattimura No. 54, Cinta Raja, Sail, Cinta Raja, Kec. Sail, Kota Pekanbaru, Riau 28127 \\ E-mail : sefronasyaiful@gmail.com
}

\begin{abstract}
Hotel Swiss-Belinn Pekanbaru is one of the 3 (three) Star Hotels in Pekanbaru. The hotel is strategically located even though it is not in the City Center and has the largest meeting building in the city of Pekanbaru, namely the SKA Convention and Exhibition (SKA Co Ex). High competition among star hotels in Pekanbaru City causes Occupancy rooms at Swiss-Belinn Hotel Pekanbaru to not meet the targets set by management. In an effort to attract customers to stay at Swiss-Belinn Pekanbaru Hotel, the management then utilized the Meeting Building and offered more event packages from other Hotels in Pekanbaru City. In terms of opportunities, currently marketing events is a good effort to increase occupancy. Through the event that is held, the tourists will choose the hotel where they stay so this will help increase the occupancy of the room in the Hotel. The reason for taking this title is to find out the event package products offered at Hotel Swiss-Belinn Pekanbaru. Then to find out the occupancy rate of the room at Swiss-Belinn Hotel Pekanbaru. In addition, it was also to find out the effect of the event on the increase in occupancy room at Swiss-Belinn Hotel Pekanbaru. The method used in this study is a qualitative descriptive method with data collection techniques in the form of observation, interviews and documentation. The results of this study, it is known that there are more event packages offered by Swiss-Belinn Hotels Pekanbaru with the advantages of each. And based on the primary data obtained by the author, it is known that the occupancy level of the Swiss-Belinn Pekanbaru hotel in the category is not high enough. In addition, after processing the data, it is known that not all event packages offered have an effect on the increase in occupancy room. There is only one package that has a high enough effect, namely the package called the Residential package. From the average known effect of the package to occupancy room is $60 \%$ of the total occupancy room.
\end{abstract}

Keywords: Event, Occupancy room, Event Package

Hotel adalah jenis akomodasi yang mempergunakan seluruh atau sebagian bangunan untuk menyediakan jasa penginapan, makan dan minum serta jasa lain bagi umum yang dikelola secara komersial (Ismayanti, 2010). Dengan kata lain hotel adalah perusahaan yang dikelola oleh pemiliknya dengan menyediakan pelayanan makanan, minuman dan fasilitas kamar untuk tidur kepada orang-orang yang sedang melakukan perjalanan dan mampu membayar dengan jumlah yang wajar sesuai dengan pelayanan yang diterima tanpa adanya perjanjian khusus.
Objek utama yang di tawarkan kepada pelanggan di sebuah hotel adalah kamar untuk menginap. Untuk itu, setiap hotel selalu mengupayakan agar occupancy selalu tinggi. Penjualan kamar hotel merupakan ujung tombak dari usaha perhotelan. Karena jika suatu hotel tidak ditunjang dengan penjualan kamar yang baik, suatu hotel tersebut tidak dapat mempertahankan kelangsungan bisnis nya. Occupancy adalah suatu keadaan sampai sejauh mana jumlah kamar terjual jika diperbandingkan dengan seluruh jumlah kamar yang tersedia untuk terjual. Occupancy merupakan tolok ukur keberhasilan dari sebuah hotel. Bahwa 
dengan tingginya occupancy di sebuah hotel, secara tidak langsung akan mempengaruhi penghasilan dan keuntungan hotel tersebut serta dinyatakan berhasil mencapai target perusahaan. Maka dari itu, pada umumnya hotel selalu berusaha untuk meningkatkan tingkat hunian kamarnya. Berbagai upaya dilakukan oleh pihak manajemen hotel untuk meningkatkan penjualan kamar.

Dalam perkembangannya, saat ini hotel bukan lagi merupakan bangunan yang menyediakan jasa penginapan dan makanan untuk melayani masyarakat. Pada saat ini hotel merupakan salah satu industri jasa dengan perkembangan yang sangat pesat. Fungsi hotel saat ini sudah mulai beralih, apabila pada awalnya hotel hanya dijadikan sebagai tempat peristirahatan saat berlibur atau berkunjung ke kota lain.

Saat ini Ballroom di hotel juga merupakan tempat yang paling banyak digunakan untuk menyelenggarakan event. Dilihat dari segi peluang, pada saat ini memasarkan event merupakan upaya yang tepat untuk hotel dalam upaya meningkatkan occupancy. Menyelenggarakan event memiliki peranan yang cukup penting dalam meningkatkan pendapatan maupun meningkatkan occupancy pada hotel.

Event merupakan suatu bentuk peristiwa dan bukan kejadian, karena secara sengaja diadakan atau diselenggarakan untuk suatu tujuan tertentu. Event erat hubungannya dengan kegiatan manusia sebagai makhluk sosial serta interaksi sosial dalam komunikasi transaksi. Ragam event amat banyak bergantung dari ide yang melandasi terlaksananya hal itu. Any Noor (2013: 8) mengatakan, event merupakan suatu kegiatan yang diselenggarakan untuk memperingati hal-hal penting sepanjang hidup manusia, baik secara individu atau kelompok yang terikat secara adat, budaya, tradisi, dan agama yang diselenggarakan untuk tujuan tertentu serta melibatkan lingkungan masyarakat yang diselenggrakan pada waktu tertentu. Dengan kata lain, event adalah sebuah program yang akan dilakukan secara terencana untuk suatu tujuan. Ragam acara sangat bergantung dari ide yang melandasi terlaksananya hal itu. Berbeda dengan kegiatan yang spontan, acara dilakukan berdasarkan rencana yang telah disusun sebelumnya.

Hotel Swiss-Belinn Pekanbaru merupakan salah satu Hotel Bintang 3 (tiga) di Pekanbaru. Sebagai hotel yang memiliki letak strategis dan mudah di akses meskipun tidak berada di pusat kota, hotel Swiss-Belinn Pekanbaru merupakan pilihan utama bagi para konsumen baik dalam menginap maupun dalam menyelenggarakan event. Peluang tersebut tidak disia siakan oleh pihak manajemen hotel Swiss-Belinn Pekanbaru, untuk memaksimalkan penyediaan fasilitas dan gedung dalam menyelenggarakan event, Hotel SwissBellin mengelola dan meresmikan SKA Convention and Exhibition (SKA Co Ex) pada tanggal 25 November 2014. SKA Co Ex merupakan gedung pertemuan terbesar di Pekanbaru dan merupakan andalan Hotel Swiss-Belinn Pekanbaru untuk menarik minat pelanggan dalam menyelenggarakan event. Tujuan utama diresmikannya SKA Co Ex adalah untuk mendukung peningkatan Occupancy di Hotel Swiss-Belinn Pekanbaru. Sebelum di resmikan SKA Co Ex, occupancy room di hotel Swiss-Belinn Pekanbaru terbilang Rendah. Walaupun tidak mengalami peningkatan yang tajam, namun sejak diresmikannya SKA Co Ex occupancy room per tahun di hotel Swiss-Belinn Pekanbaru mengalami kemajuan yang cukup bagus.

Tabel 1. Data Occupancy room \& Pelaksanaan Event/tahun di Hotel Swiss-Belinn Pekanbaru, tahun 2012-2018

\begin{tabular}{|l|l|l|l|l|l|l|l|}
\hline Tahun & 2012 & 2013 & 2014 & 2015 & 2016 & 2017 & 2018 \\
\hline $\begin{array}{l}\text { Occupancy } \\
\text { room }\end{array}$ & $35 \%$ & $45 \%$ & $55 \%$ & $57 \%$ & $60 \%$ & $55 \%$ & $58 \%$ \\
\hline Event & 36 & 40 & 72 & 96 & 120 & 190 & 192 \\
\hline
\end{tabular}


Sumber : HRD Swiss-Belinn Pekanbaru.

Dari tabel 1 tersebut dapat di jelaskan bahwa meskipun mengalami peningkatan yang lumayan diawal sejak diresmikannya SKA CO Ex, namun peningkatan tersebut tidak maksimal. Dari tahun ke tahun sejak diresmikannya SKA CO Ex pada tahun 2014, tingkat occupancy tidak mengalami kenaikan atau kemunduran. Setiap tahunnya jumlah event terus meningkat di SKA Co Ex namun hal tersebut tidak mampu mendongkrak secara maksimal tingkat occupancy di hotel Swiss-Belinn Pekanbaru. Event merupakan peluang yang cukup bagus dalam menaikkan occupancy, namun pada kenyataannya peningkatan occupancy tidak terlalu mengalami kenaikan yang signifikan. Berdasarkan teori yang dicetuskan oleh Any Noor dalam bukunya mengenai pengaruh event ( 2009:36) dan dengan adanya Ballroom yang cukup besar dan mewah seharusnya tingkat occupancy hotel Swiss-Belinn Pekanbaru dapat didongkrak sampai $80 \%-90 \%$ apabila di tinjau dari segi fasilitas event yang tersedia dan banyak nya jumlah event yang diselenggarakan di Co Ex setiap tahunnya.

Berdasarkan latar belakang masalah tersebut, maka rumusan permasalahan yang diangkat dalam penelitian ini adalah "Bagaimana Pengaruh Event terhadap peningkatan Occupancy pada Hotel Bintang 3 (***) di Pekanbaru: Study Kasus pada Hotel Swiss-Belinn Pekanbaru".

Event, yaitu suatu kegiatan yang diselenggarakan untuk memperingati hal hal penting sepanjang hidup manusia, baik secara individu atau kelompok yang terikat secara adat, budaya, tradisi, dan agama yang diselenggarakan untuk tujuan tertentu serta melibatkan lingkungan masyarakat yang diselenggarakan pada waktu tertentu. Dengan kata lain, event adalah sebuah program yang dilakukan secara terencana untuk tujuan tertentu. Ragam acara amat banyak tergantung dari ide yang melandasi terlaksananya suatu event.
Hotel Occupancy, yaitu suatu keadaan sampai sejauh mana jumlah kamar terjual jika diperbandingkan dengan seluruh jumlah kamar yang tersedia untuk dijual. Jumlah penjualan kamar merupakan tolok ukur keberhasilan dari sebuah hotel. Tujuan utama penjualan kamar yaitu meningkatkan occupancy hotel. Kemudian mendatangkan keuntungan / laba yang disertai tercapai nya tujuan utama perusahaan. Yaitu occupancy yang tinggi. Bahwa dengan tingginya occupancy di sebuah hotel, secara tidak langsung akan mempengaruhi penghasilan dan keuntungan hotel tersebut

Menurut Any Noor (2013: 8), event merupakan suatu kegiatan yang diselenggarakan untuk memperingati halhal penting sepanjang hidup manusia, baik secara individu atau kelompok yang terikat secara adat, budaya, tradisi, dan agama yang diselenggarakan untuk tujuan tertentu serta melibatkan lingkungan masyarakat yang diselenggrakan pada waktu tertentu. Dengan kata lain, event adalah sebuah program yang akan dilakukan secara terencana untuk suatu tujuan. Ragam acara amat banyak bergantung dari ide yang melandasi terlaksananya hal itu. Berbeda dengan kegiatan yang spontan, acara dilakukan berdasarkan rencana yang telah disusun sebelumnya.

Seiring dengan perkembangan jaman dan pertumbuhan jumlah populasi di dunia yang sangat cepat, mayoritas dari populasi membutuhkan perjalanan sebagai salah satu cara untuk menghilangkan kepenatan dan melarikan diri dari rutinitas yang padat. Namun, pada jaman era globaliasasi sekarang ini, tujuan dari berjalan jalan menjadi heterogen dan terdapat banyak aspek yang mempengaruhinya seperti; kepentingan usaha, kepentingan agama, kepentingan keluarga dan berelasi, dan lain sebagainya.

Salah satu dari tujuan tersebut yaitu untuk menghadiri acara, seperti acara pertemuan rapat, acara perkumpulan/reuni, acara pernikahan keluarga dan lain - lain. Menurut Any Noor (2013: 8), acara 
merupakan suatu kegiatan yang diselenggarakan untuk memperingati hal hal penting sepanjang hidup manusia baik secara individu atau kelompok yang terkait secara adat, budaya, tradisi dan agama yang diselenggarakan untuk tujuan tertentu serta melibatkan lingkungan masyarakat yang diselenggarakan pada waktu tertentu.

Event memiliki beberapa karakteristik karena setiap penyelenggaraan event harus memiliki ciri tersendiri. Karakteristik event menurut Any Noor (2013: 14), ada lima yaitu keunikan, perishability, intangibility, suasana, pelayanan dan interaksi personal.

\section{Keunikan}

Kunci suksesnya sebuah event adalah pengembangan ide.Setiap event harus memiliki sesuatu yang berbeda dengan event lain.Event yang pernah diselenggarakan pastinya masih dapat diulangi pada kesempatan lain, misalnya event yang biasa diselenggarakan secara reguler. Tetapi, keunikan harus tetap muncul pada setiap penyelenggaraan event meskipun memiliki tema yang sama. Keunikan dapat berasal dari tema yang diambil, penampilan kreatif dari peserta yang ikut serta dalam event, lingkungan sekitar, pengunjung event serta beberapa hal lainnya sehingga membuat event menjadi unik dan berbeda dari event tahun sebelumnya.

\section{Perishability / Mudah Rusak}

Setiap event yang diselenggarakan tidak akan pernah sama. Dua event yang sama diselenggarakan pada waktu dan tempat yang sama pastinya tidak akan menghasilkan event yang sama pula. Perishability berhubungan dengan penggunaan fasilitas untuk penyelenggaraan event.

\section{Intangibility / Tidak dapat dipaham}

Setelah menghadiri event, yang tertinggal di benak pengunjung adalah pengalaman yang mereka dapatkan dari penyelenggaraan event. Hal ini merupakan tantangan untuk merubah bentuk pelayanan intangibility menjadi sesuatu yang berwujud, sehingga sekecil apapun wujud yang digunakan dalam event mampu mengubah persepsi pengunjung.

\section{Suasana dan Pelayanan}

Suasana dan Pelayanan merupakan karakteristik yang penting pada saat keberlangsungan event. Event yang dilangsungkan di saat suasana yang tepat akan menghasilkan sukses besar, tetapi sebaliknya kegagalan event dihasilkan karena suasana yang tidak tepat. Suasana yang dibangun harus sesuai dengan tema tersebut, musik yang tepat, makanan dan minuman yang baik, dan keseluruhannya telah ditata secara sempurna sesuai tema sehingga kekhusukan dari kegiatan tersebut dapat terjaga.

\section{Interaksi personal}

Interaksi personal dari pengunjung merupakan kunci sukses penyeleggaraan event. Karena pengunjung akan merasa menjadi bagian dari dalam event tersebut.

Event atau acara merupakan sebuah program yang akan dilakukan dengan terencana untuk mencapai suatu tujuan. Pada proses yang biasanya yaitu menentukan konsep/ tema/ tipe dari acara, lalu menentukan apa saja tujuan dari acara tesebut. Tetapi dapat juga, yang dilakukan pertama - tama adalah menentukan tujuan, lalu dari tujuan akan mendapatkan gambaran seperti apa acara yang akan direncanakan. Tidak ada yang salah dari pilihan kedua proses tersebut, tetapi yang mutlak adalah harus adanya kesinambungan antara konsep acara dengan tujuan acara.

Any Noor (2013:9) membagi jenis event berdasarkan kategori special event, yakni: Leisure event, Cultural event, Personal event dan Organizational event. Setiap event yang diselenggarakan baik event dalam skala kecil ataupun skala besar pasti memiliki dampak. Dampak penyelenggaraan event tersebut dapat berupa dampak positif maupun dampak negatif. Dampak positif dan negatif tersebut akan berpengaruh terhadap lingkungan, sosial budaya, politik, pariwisata dan ekonomi. Dampak-dampak tersebut tidak dapat dipisahkan dari event. Dampak yang mungkin timbul perlu diprediksi sejak awal event direncanakan. Tentunya dampak 
tersebut akan berpengaruh terhadap bagaimana pengelolaan event sehingga penyelenggara event harus menyusun rencana yang dapat memberikan keseimbangan kepada seluruh pihak yang terlibat dalam penyelenggaraan event.

Any Noor (2009:36) mengatakan beberapa pengaruh positif pada sisi ekonomi dan pariwisata yang timbul dari penyelenggaraan event yaitu : Promosi Daerah Wisata, Peningkatan Jumlah Kunjungan Wisatawan, Peningkatan Waktu Lama Tinggal Wisatawan, Peningkatan Pendapatan, dan Penciptaan Lapangan Kerja.

Hotel berasal dari kata hostel. Konon hostel diambil dari bahasa Perancis yang berasal dari bahasa latin, yaitu Hostes. Bangunan publik ini sudah disebut-sebut sejak akhir abad ke-7. Maknanya sebagai tempat penampungan buat pendatang atau bisa juga sebagai bangunan menyedia pondokan dan makanan untuk umum. Jadi, pada mulanya hotel diciptakan untuk melayani masyarakat. Definisi dari hotel adalah jenis akomodasi yang mempergunakan seluruh atau sebagian bangunan untuk menyediakan jasa penginapan, makan dan minum serta jasa lain bagi umum yang dikelola secara komersial (Ismayanti, 2010).

Menurut Ismayanti (2010), tipe hotel dapat dibagi menjadi beberapa aspek sebagai berikut :

1. Berdasarkan lama tinggal, hotel dibedakan menjadi seperti berikut ini.

a. Transient Hotel adalah hotel yang diinapi oleh tamu selama 24 jam hingga tiga hari dan tamu dikenakan biaya sewa kamar harian. Tamu yang menginap di hotel ini sering disebut sebagai short stay guest.

b. Semi residential Hotel adalah Hotel yang ditiinggali tamu selamanya Tujuh hingga 30 hari tamu dikenakan biaya sewa kamar mingguan.

c. Residential Hotel adalah hotel yang ditinggali tamu selama lebih dari 30 hari hingga setahun dan tamu dikenakan biaya sewa kamar bulanan. Tamu yang menginap di hotel ini disebut long stay guest.

1. Berdasarkan lokasi, hotel dibedakan menjadi seperti berikut ini.

a. City Hotel adalah hotel yang berlokasi di perkotaan.

b. Resort Hotel merupakan hotel yang yang berlokasi di daerah wisata, seperti pantai atau pegunungan.

c. Airport Hotel, yaitu hotel yang berlokasi di sekitar bandara.

2. Berdasarkan ukuran dan jumlah kamar, hotel dibedakan menjadi :

a. Hotel kecil atau small hotel dengan kapasitas kurang dari 15 kamar.

b. Hotel medium atau average hotel dengan kapasitas sekitar 15-29 kamar.

c. Hotel di atas rata-rata atau above average hotel dengan kapasitas sekitar 30-60 kamar.

d. Hotel besar atau large hotel dengan kapasitas lebih dari 60 kamar.

\section{METODE}

Penelitian ini telah penulis lakukan di Hotel Swiss-Belinn Pekanbaru, RiauIndonesia, sebuah hotel yang bertaraf nasional. Populasi dalam penelitian ini adalah seluruh staff banquet department yang berjumlah 15 orang juga seluruh staff front office department yang berjumlah 10 orang. Karena populasinya berjumlah kurang dari 100 maka peneliti mengambil sampel dengan jumlah keseluruhan populasi yaitu sejumlah 25 orang. Dengan demikian, besarnya sampel dalam penelitian ini adalah 25 orang sebagai narasumber.

Adapun teknik pengumpulan data observasi, studi dokumen, wawancara dan studi pustaka. Data yang diperoleh dari hasil wawancara dan observasi di pilah pilah dan di klasifikasikan menurut jenisnya dan kemudian dianalisis dan diolah dengan menggunakan metode deskriptif kualitatif. 


\section{HASIL}

Berdasarkan dari olahan data di atas, dapat diketahui bahwa penyelenggaraan event package yang paling berpengaruh terhadap peningkatan occupancy adalah event residential package yaitu rata rata sebesar 23,65\% mempengaruhi occupancy. Sementara itu event yang paling sedikit berpengaruh terhadap occupancy adalah event wedding yaitu rata rata sebesar 1,52\%. Agar lebih mudah di pahami.

Dari data primer yang sudah diolah oleh peneliti, maka dapat di peroleh rata rata tingkat penjualan kamar melalui event yang diselenggarakan di hotel Swiss-Belinn Pekanbaru. Bahwa pada bulan oktober tingkat penjualan kamar melalui event adalah sebesar 22,95 \% pada bulan November sebesar $30,48 \%$ dan pada bulan desember sebesar 33,25 \%. Dapat dilihat bahwa occupancy tertinggi melalui event adalah pada bulan desember yaitu sebesar 33,25\% dan rata rata tingkat occupancy room melalui event di hotel Swiss-Belinn Pekanbaru adalah sebesar 28,89\%.

Berdasarkan dari hasil rekapitulasi pengaruh event terhadap occupancy tersebut maka dapat dilakukan pengolahan data untuk mengetahui tingkat persentasi pengaruh event terhadap occupancy di hotel Swiss-Belinn Pekanbaru. Bahwa persentase pengaruh event terhadap occupancy pada bulan oktober adalah sebesar 54,35\% dari total occupancy, pada bulan November pengaruh event terhadap occupancy adalah sebesar 66, $55 \%$ dari total occupancy dan pada bulan desember pengaruh event terhadap occupancy adalah sebesar $60,73 \%$ dari total occupancy. Dari data diatas dapat disimpulkan bahwa sebesar 60,54\% occupancy di Hotel Swiss-Belinn Pekanbaru diperoleh dari hasil event yang diselenggarakan di hotel tersebut.

Occupancy room di hotel Swis Bellin Pekanbaru dapat dikategorikan tidak cukup tinggi. Jika dilihat jumlah kamar yang tersedia per 30 hari adalah 3240 (100\%) kamar dan yang terjual pada bulan oktober hanya 1368 kamar $(42,22 \%)$, terjual pada bulan november adalah 1484 kamar $(45,80 \%)$ dan pada bulan desember terjual 1774 kamar (54,75\%). Dari data diatas dapat dilihat bahwa persentase occupancy room tertinggi hanya $54,75 \%$. Pada bulan tersebut occupancy mencapai angkat $54,75 \%$ dikarena ada beberapa grup dari pemerintahan yang mengadakan event untuk perayaan akhir tahun dan menggunakan Hotel Swiss-Belinn Pekanbaru sebagai tempat menginap sekaligus mengadakan event. Apabila di rata ratakan maka tingkat occupancy room hotel Swiss-Belinn Pekanbaru adalah 47,49 $\%$. Untuk lebih jelasnya, penulis menggambarkan tingkat occupancy room tersebut kedalam grafik agak lebih mudah dipahami.

Dalam pelaksanaan, event memberikan beberapa pengaruh bagi Hotel Swiss-Belinn Pekanbaru setelah diadakannya Paket untuk Penyelenggaraan Event di Hotel Swiss-Belinn Pekanbaru khususnya di Ska Co Ex, diantaranya meningkatnya jumlah tamu yang berkunjung dan menginap di Hotel SwissBelinn Pekanbaru. Berikut penulis sajikan pengaruh event terhadap occupancy di Hotel Swiss-Belinn Pekanbaru.

\section{PEMBAHASAN}

Pengaruh event meeting terhadap occupancy pada bulan oktober adalah 1,85 $\%$ pada bulan November adalah 2,09 \% dan pada bulan desember $1,48 \%$. Event meeting berpengaruh cukup kecil terhadap occupancy room di Hotel Swiss-Belinn Pekanbaru. Dari data tersebut dapat diketahui bahwa pengaruh event meeting tertinggi yaitu pada bulan november sebesar $2,09 \%$. Dan Persentasi rata rata pengaruh event meeting terhadap occupancy adalah $1,80 \%$. Pada bulan November, pengaruh event meeting terhadap occupancy mencapai $2,09 \%$ hal ini disebabkan oleh banyaknya reservasi untuk meeting yang dipesan oleh perusahaan swasta yang memiliki beberapa pejabat komisaris dari Luar Negeri. Karena Hotel Swiss-Belinn 
Pekanbaru merupakan Hotel yang sudah berskala Internasional maka para pejabat komisaris perusahaan swasta tersebut memilih menginap di Hotel tersebut sehingga pengaruh event meeting sedikit lebih tinggi di bulan November. Paket event meeting menjadi produk unggulan di Hotel SwissBelinn Pekanbaru bukan karena mampu menjual kamar namun dijadikan produk unggulan karena mampu meningkatkan nilai image dan brand Hotel yang sudah Berskala Internasional. Meskipun tidak mendongkrak occupancy room dengan maksimal namun event meeting mampu mendongkrak popularitas Hotel Swiss-Belinn Pekanbaru sebagai Hotel yang berkesan mewah dengan meeting room yang luxury sesuai dengan brand yang dimiliki sebagai Swiss-Belhotel Group International. Pada event meeting, yang lebih dominan dijual adalah jasa (service) mengenai kemudahan kemudahan dalam persiapan meeting, kemewahan ruangan meeting, dan jaminan privasi yang sudah terjamin sehingga benar benar menggambarkan kesan mewah dan private pada saat meeting. Konsep ini cukup cocok untuk perusahaan perusahaan swasta modal asing yang memiliki pejabat pejabat komisaris dari Luar Negeri yang pada umumnya sangat menginginkan ruangan yang bersifat private pada saat meeting ataupun kegiatan lainnya.

Pengaruh event wedding terhadap occupancy pada bulan oktober adalah 1,48 $\%$ pada bulan November $1,85 \%$ dan pada bulan desember 1,23 \%. Event wedding berpengaruh cukup kecil terhadap occupancy room di Hotel Swiss-Belinn Pekanbaru. Dari data tersebut dapat diketahui bahwa pengaruh tertinggi event wedding terhadap occupancy yaitu pada bulan November sebesar 1,85\% dan persentasi rata rata pengaruh event wedding terhadap occupancy adalah 1,52\%. Event wedding cukup banyak diselenggarakan di Ska Co Ex Pekanbaru namun tidak begitu berpengaruh terhadap Occupancy Hotel Swiss-Belinn Pekanbaru hal itu disebabkan oleh tamu yang berkunjung sebagai undangan di event wedding tersebut jarang berasal dari luar kota. Pada umumnya hanya dari daerah pekanbaru sehingga undangan tersebut tidak perlu menginap. Tamu tamu yang menghadiri undangan tersebut pada umumnya hanya berkunjung selama acara dilangsungkan. Selain itu, dikarenakan event wedding merupakan event jangka pendek yang hanya membutuhkan waktu maksimal 4 (empat) jam sampai selesai sehingga tidak dibutuhkan kamar untuk menginap bagi para undangan. Kamar yang di pesan pada umumnya hanya untuk pasangan yang menikah dan merupakan kamar suite.

Pengaruh ghatering package terhadap occupancy pada bulan oktober adalah $1,11 \%$ pada bulan November 1,85 $\%$ dan pada bulan desember $2,77 \%$. Dari data tersebut dapat diketahui bahwa pengaruh tertinggi event ghatering adalah pada bulan desember yaitu $2,77 \%$. Event ghatering berpengaruh cukup kecil untuk occupancy room di Hotel Swiss-Belinn Pekanbaru. Karena kegiatan ghatering pada umumnya hanya dilakukan pada waktu waktu tertentu oleh perusahaan. Di Hotel Swiss-Belinn, event ghatering cukup jarang dilakukan dikarenakan biaya sewa gedung yang cukup tinggi sementara manfaat yang di dapat kurang maksimal (indoor). Kegiatan Ghatering akan lebih maksimal jika diselenggarakan di luar ruangan (outdoor). Hanya perusahaan perusahaan tertentu yang mengadakan event ghatering di Hotel Swiss-Belinn. Biasanya perusahaan tersebut sudah memiliki kontrak kerjasama dengan Hotel Swiss-Belinn sehingga mampu mengadakan event ghatering di hotel tersebut. Pada tabel diatas, diketahui bahwa pada bulan Desember event ghatering berpengaruh $2,77 \%$ terhadap occupancy room hal itu disebabkan oleh tamu undangan perusahaan yang mengadakan acara ghatering berasal dari cabang cabang perusahaan dari luar daerah Kota Pekanbaru. Karena berasal dari luar kota maka penyelenggara memesan kamar untuk tamu undangan tersebut. 
Namun bulan bulan lainnya rata rata event ghatering hanya berpengaruh sekitar 1,91\% terhadap peningkatan occupancy di hotel Swiss-Belinn Pekanbaru.

Pengaruh residential package terhadap occupancy pada bulan oktober adalah $18,51 \%$ pada bulan November 24,69 $\%$ dan pada bulan desember $27,77 \%$. Dari data tersebut dapat diketahui bahwa pengaruh tertinggi event residential terhadap occupancy adalah pada bulan desember yaitu sebesar $27,77 \%$. Event residential memiliki pengaruh cukup tinggi terhadap occupancy room di Hotel Swiss-Belinn Pekanbaru. Salah satu faktor yang menyebabkan event residential memiliki pengaruh yang tinggi adalah dikarenakan event residential sudah sekaligus menjual kamar pada paketnya dan di pesan minimal 3 hari 2 malam. Paket ini khusus untuk event event yang membutuhkan waktu lebih dari 1 (satu) hari. Seperti pelatihan (training) karyawan yang dilakukan oleh BUMN (Badan Usaha Milik Negara) dan Perangkat Perangkat Pemerintah yang sering mengadakan event dengan jangka menginap yang lebih dari 1 malam. Pada bulan Desember, pengaruh event residential terhadap occupancy mencapai $27,77 \%$ dikarenakan banyak nya event yang diselenggarakan oleh pemerintah. Selain itu, faktor yang menyebabkan event residential memiliki pengaruh yang cukup tinggi terhadap peningkatan occupancy adalah harga yang ditawarkan sudah cukup murah apabila dilihat dari manfaat paketnya yang sudah termasuk semuanya (all include).

\section{SIMPULAN}

Dari hasil olahan data penelitian dan persentasi pengaruh event terhadap peningkatan occupancy di Hotel SwissBelinn Pekanbaru dapat di tarik kesimpulan bahwa event cukup berpengaruh dalam meningkatkan occupancy di Hotel SwissBelinn Pekanbaru namun tidak signifikan. Meskipun berpengaruh terhadap peningkatan occupancy namun tidak mampu mendongkrak secara maksimal peningkatan occupancy di Hotel Swiss-Belinn Pekanbaru.
Hal ini sangat bertolak belakang dengan teori yang disampaikan oleh Any Noor (2009:36) yang mengatakan bahwa event akan mendongkrak kebutuhan akomodasi dan lama tinggal wisatawan. Pada penelitian yang dilakukan oleh penulis diketahui bahwa event memang cukup berpengaruh namun tidak signifikan.

\section{DAFTAR RUJUKAN}

Agus Sulastiyono. (2004). Manajemen Penyelenggaraan Hotel. Bandung : Penerbit CV Alfabeta.

Adinegara, Gusti Ngurah Joko dan Pramono. 2011. Dampak krisis Global pada Tingkat Hunian Kamar Hotel Berbintang dan Non Bintang di Kabupaten Bandung, Jurnal Perhotelan dan Pariwisata, No. 2, Vol 1, Hal:1-14.

Arikunto, Suharsimi. 2006. Prosedur Penelitian Suatu Pendekatan Praktik Edisi

Revisi. Jakarta: Rineka Cipta.

Bagyono. 2005. Pariwisata Dan Perhotelan. Bandung : Alfabeta.

Damardjati, R.S. 2006. Istilah Istilah Dunia Pariwisata. Jakarta : PT Pradnya Paramita

Endar Sugiarto. 2002. Psikologi Pelayanan dalam Industri Jasa. Jakarta: Gramedia Pustaka Utama.

Ismayanti. 2010. Pengantar Pariwisata. Jakarta : PT. Gramedia Widisarana Indonesia

Michael H. Walizer, Paul L Wienir. 1993. Metode dan Analisis Penelitian : Mencari Hubungan Jilid 2. Jakarta : Erlangga. 
Noor, Any. 2009. Manajemen Event. Bandung: Alfabeta.

2013. Manajement Event Edisi Revisi. Bandung: Alfabeta.

Pendit, Nyoman . 2003. Pengantar Ilmu Pariwisata. Jakarta: PT Pradaya Paramita

Sihite, Richard, 2000, Hotel Manajemen (Pengelolaan Hotel), SIC, Surabaya.

Sugiyono. 2010. Metode Penelitian Kuantitatif Kualitatif dan R\&D. Bandung:

Alfabeta.

2013. Metode Penelitian Pendidikan Pendekatan Kuantitatif, Kualitatif, dan R\&D. Bandung: Alfabeta.

Vicky hanggara, 2009, Pengertian Tingkat Hunian Hotel

(http://vickyhanggara.blog.friendster.com/20 09/pengertian-tingkat hunian hotel/)

(https://venuemagz.com/profile/firdaus-walikota-pekanbaru-kami-fokus-pada wisata-mice/)

(https://travel.kompas.com/read/2018/03/10/ 164700027/mice-dan-event-dorongokupansi-hotel-di-pekanbaru.) 